\title{
Nodular features from Proterozoic Sonia Sandstone, Jodhpur Group, Rajasthan: A litho-biotectonic perspective
}

\author{
Arvind Singh ${ }^{1}$, Vikash Anand ${ }^{1,3}$, Prabhas Pandey ${ }^{2}$ and Partha Pratim Chakraborty ${ }^{1, *}$ \\ ${ }^{1}$ Department of Geology, University of Delhi, Delhi 110 007, India. \\ ${ }^{2}$ Ramlal Anand College, South Campus, University of Delhi, New Delhi 110 021, India. \\ ${ }^{3}$ Present address: Geological Survey of India, Central Head Quarters, Kolkata, India. \\ ${ }^{*}$ Corresponding author.e-mail: parthageology@gmail.com
}

\begin{abstract}
The Sonia Sandstone of Proterozoic Jodhpur Group, Marwar Supergroup, exposed around the Sursagar dam area of Jodhpur town, Rajasthan exposes two varieties of nodular features, often spectacular in shape and size. On the basis of mode of occurrence (intra- or interbed) and stratal involvement (single or multiple) the features are classified as Type I and II. From granulometric and microscopic (optical and scanning electron) studies carried out on sandstones from the nodules and their host sandstones, geochemical analysis (SEM-EDAX) of intragranular cement present within Type I nodules, and appreciation of control of associated fracture system within Type II nodules, it is proposed that the two types of nodules vary in their formative mechanism and stage of formation. While Type I nodules are identified as product of processes operative at the early diagenetic, pre-lithification stage, the Type II nodules are undoubtedly the result of post-lithification origin triggered by formation of fracture system. Here we propose generation of vapour pressure (not exceeding the overlying hydrostatic pressure) by decay of thin, laterally impersistent organic mat as the causal factor for intrabed nodule (Type I) formation, which forced rarefication of local grain packing vis-a-vis early diagenetic silica cementation. The study warrants necessity of more studies on nodules to understand possible roles of organic matter and bedtransgressive fracture systems in their formation, going beyond the generalised secondary mineralisation hypothesis.
\end{abstract}

\section{Introduction}

Nodular features in sedimentary rocks are commonly interpreted as products of post-depositional preferential solution and secondary mineralisation in course of diagenesis (Pettijohn 1984; Moller and Kvingan 1988). Described mostly from the carbonate, fine-grained siliciclastic and cherty sediments, the nodules are often related with early diagenetic cementation history (Rahmani 1970; Theakstone
1981; McBride et al. 1994; Banerjee et al. 2006b; Banerjee and Jeevankumar 2007), although claims favouring burial and mechanical compaction origin can also be found in literature (Raiswell 1971). Within the carbonate sediments, studies of nodules progressed further as it is felt that the results will help in understanding the nature of fluid flow through heterogeneous calcareous sediments, evolution in petrophysical properties and in course, may guide in improved management of aquifers and

Keywords. Sonia Sandstone; nodule; early cementation; lithification; fracture. 
hydrocarbon reservoirs. Elongated calcite concretions within sandstones are identified as products of paleo-groundwater flow in the saturated zone and projected as a means for rapidly estimating the major axis of the permeability correlation structure over large areas (Mozley and Davis 1996; Pomar et al. 2004). In comparison, less attention has been paid on the nodules present in intermediateand coarse-grained sandstones (Molenaar and Martinius 1990); available studies are confined within carbonate cemented nodules with rare reference to silica cemented varieties. The present work aims at filling the gap with documentation of an array of intra- and inter-bed nodular features, early silica cemented at cases, from mediumgrained sandstones belonging to the Proterozoic Sonia Sandstone in the Jodhpur Group of Marwar Supergroup, Rajasthan.

Nodules formed in the diagenetic or postlithification stages can assume any shape, size and position (parallel/perpendicular to bedding plane) depending on the availability of suitable locale/s for secondary precipitation. Conforming this understanding, the nodules described in this study also vary widely in shape, geometry and mode of occurrence. In this study, we describe two varieties of nodular features, viz., Type I and II and aim at making genetic distinction between the two varieties by taking into consideration lithological, structural and/or possible early diagenetic control/s on their formation.

\section{Geological background}

The Marwar basin represents the repository of endProterozoic geological events in the Indian shield at its north-western submerged continental shelf (Chauhan 1999; Valdiya 1999). The Marwar Supergroup, traditionally referred as the Trans-Aravalli Vindhyans, overlies Malani Rhyolites of Neoproterozoic age (Rathore et al. 1996, 1998; Malone et al. 2008) and is subdivided into three groups, viz., Jodhpur Group, Bilara (Hanseran) Group and Nagaur Group, in order of superposition. From stable isotope $\left({ }^{13} \mathrm{C}\right.$ and $\left.{ }^{18} \mathrm{O}\right)$ stratigraphy within the carbonates of Bilara Group, Mazumdar and Bhattacharya (2004) proposed its deposition transgressing the Neoproterozoic-early Cambrian ( $\mathrm{Pc}-\mathrm{C})$ boundary.

The basal Jodhpur Group is subdivided into three formations, viz., Pokhran boulder bed, Sonia Sandstone Formation and Girbakhar Formation (Pareek 1984; Das Gupta and Bulgauda 1994; Das Gupta 1996; figure 1a, b). The Sonia Sandstone Formation and the Girbakhar Formation together is informally referred to as the Jodhpur Sandstone and has drawn attraction of sedimentologists and paleobiologists for its exceptional preservation of sedimentary and microbial mat structures (Sarkar et al. 2008, 2012; Samanta et al. 2011; Bose et al. 2012). The arenaceous Sonia Sandstone Formation ( $\sim 60$ m thick), host of studied nodular structures, is undeformed and unmetamorphosed; overlie and interfinger with acid volcanic rocks of Malani Rhyolite and is unconformably overlain by the argillaceous sediments of the Girbakhar Formation (Samanta et al. 2011). Recently, Sarkar et al. (2008) carried out process-based facies and paleoenvironmental analysis on the rocks of the Sonia Sandstone and distinguished three genetic subdivisions; a coastal marine assemblage sandwiched between two subaerial-fluvial successions. Appreciating the interplay between marine (tide, wave) and eolian agents in a shallow coastal setting and considering the relative dominance of these depositional agents, Sarkar et al. (2005, 2008) classified the middle marine subdivision into three constituent facies types, viz., lower (A), middle (B) and upper $(\mathrm{C})$, in order of superposition. While the lower and upper facies (facies A and C) represent wave-dominated shallow to deep neritic paleoenvironmental condition, the middle facies B with abundant signatures of eolian activity is identified as product of supra-littoral zone representing the backshore-foreshore transition. The wide spectrum and abundant examples of microbial mat or matderived structures reported from the Sonia Sandstone (Sarkar et al. 2008; Samanta et al. 2011) are considered to impart enough cohesiveness in otherwise granular sandstones that helped in frequent preservation of delicate primary sedimentary structures and their replication in the overlying beds. The nodules described in this article are confined within the upper marine part of the Sonia Sandstone, i.e., the upper C2 subfacies of Sarkar et al. (2008) and are best exposed in quarry sections near Sursagar dam area, $\sim 7 \mathrm{~km}$ in the north-west from the Jodhpur town (figure 1a).

\section{Methodology}

It is likely that sediment parameters and/or environmental conditions favoured cementation at distinct spots, now they are represented by nodules. Taking this into consideration, samples were collected from two different categories of nodules and their associated sandstones for carrying out granulometric study. The texture and cement content of samples have been qualitatively determined by means of thin-section microscopy and quantified by point counting, wherever necessary. Samples from Type-I nodules are also studied by using Scanning 


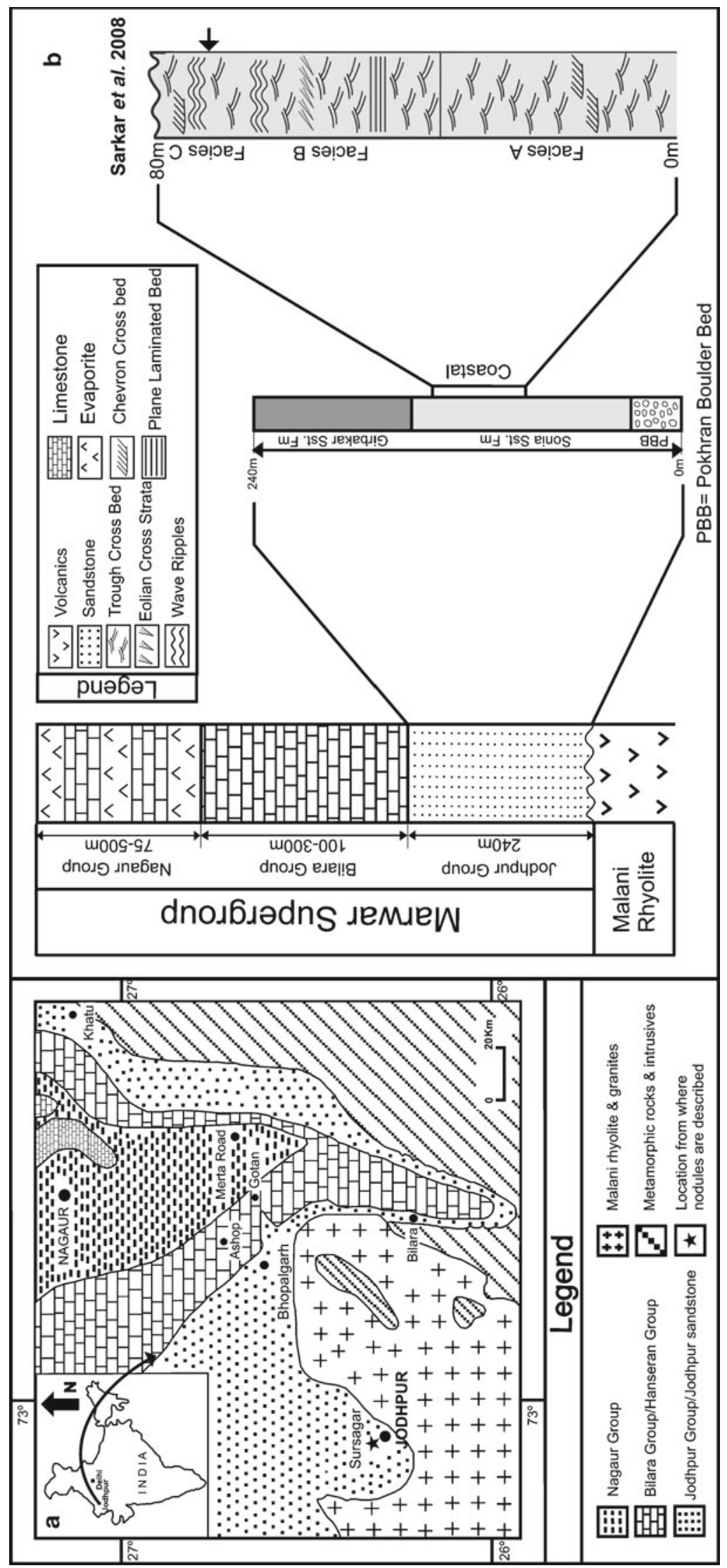

茨

료

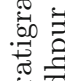

苟苛

อ눙

藏

药

은

获

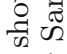

芯

过

.ี

तె

记

光.

पํํ유

.0ี

은

高告

ঔ

24.

다응

कृ

A

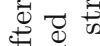

ฮี

눙

웡

$\exists$ E

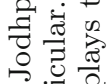

च 击

范

유.

윙

인

离.

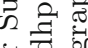

สี

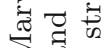

से

宅

द 80

శึ่ .0

की

$\triangle$ क्ष

ฮิ ڤ્屯

늘 
Electron Microscope - Electron Dispersive X-ray (SEM-EDAX) at Department of Geology, University of Delhi to check (i) the presence of organic matter, if any, and (ii) to characterise the geometry and composition of inter-granular cement. Fresh surfaces were obtained by breaking samples to avoid contamination of modern pollutants and special care was taken by coating the samples with gold maintaining appropriately controlled coating time (20 to 30 seconds) for observation under SEM and analysis with EDAX. As our SEM study was aimed towards getting definitive about the presence of organic matter, we avoided carbon coating to rule out possibility of carbon $(\mathrm{C})$ contamination and also took care by controlling the coating time of $\mathrm{Au}$ as it is known to produce bacteria-like artefacts if the coating time is not appropriately controlled (Folk and Lynch 1997).

High-resolution sampling was carried out from base to top in the large-scale Type-II nodules and their associated sandstones to constrain lithological control, if any, behind the spectacular pitcher shape of the nodules (described later). Twelve thin sections were prepared for petrography and granulometric analysis. Sizes of 350-400 grains are measured in each thin section and the obtained data are used for reconstruction and comparison between the cumulative frequency curves of grain size distributions of nodules, their host sandstones and sandstones from the underlying and overlying strata. Considering the confinement of Type-II nodules between sets of fracture and the involvement of strata with different thickness (thick- and thin-bedded), attempts are made to sort out relative role of fracture and lithology in framing the shape of the nodules, individually or in combination. Stereo-plotting of fracture attitudes helped us in drawing inference on possible role of fractures behind unique shapes of the nodules.

\section{Description of nodules}

Alternation between thick (av. thickness $1.12 \mathrm{~m}$ ) and thin (av. thickness $0.12 \mathrm{~m}$ )-bedded sandstones constitute the basic lithological motif of the stratigraphic section in which the nodules are best developed. While the thick-bedded units are internally massive, chevron-cross stratified or parallel laminated (figure 2), the thin-bedded ones are commonly ripple cross-laminated. Whereas Type I is bed confined and small (diam. in $\mathrm{cm}$ ) in dimension, nodules of the second type (Type II) transgress several bed boundaries and are large (diam. in $\mathrm{m}$ ) in scale.

\subsection{Type $I$}

This variety of nodules is domal in shape, 4.5$7.0 \mathrm{~cm}$ in diameter, $1.5-2.0 \mathrm{~cm}$ in relief and observed projecting out at bedding perpendicular sections (figure 3). With half-sphere geometry, these domes are observed either in isolation or coalesced one another assuming a bi-lobate geometry. All domes are randomly distributed, and have relatively steep sides with a dip angle $60^{\circ}-70^{\circ}$. Presence of any kind of feeder vent is not observed. Both domes and their host sandstones are with grain-supported fabric and internally massive in character. Granulometric study revealed average grain size $\left(\mathrm{M}_{\mathrm{z}}(\varnothing)\right)$, grain sorting $\left(\sigma_{i}(\varnothing)\right)$ and skewness $\left(\mathrm{Sk}_{\mathrm{i}}\right)$ values as $1.47 \varnothing, 0.62 \varnothing$ and 0.30 , within sandstones from the nodules and $2.06 \varnothing, 0.63 \varnothing$ and 0.30 , respectively in surrounding sandstones (figure 4, table 1). The two sandstones, however, differ significantly in their intergranular cement content; sandstones from the nodules record $\sim 9 \%$ more cement content in comparison with their surrounding sandstones (table 1).

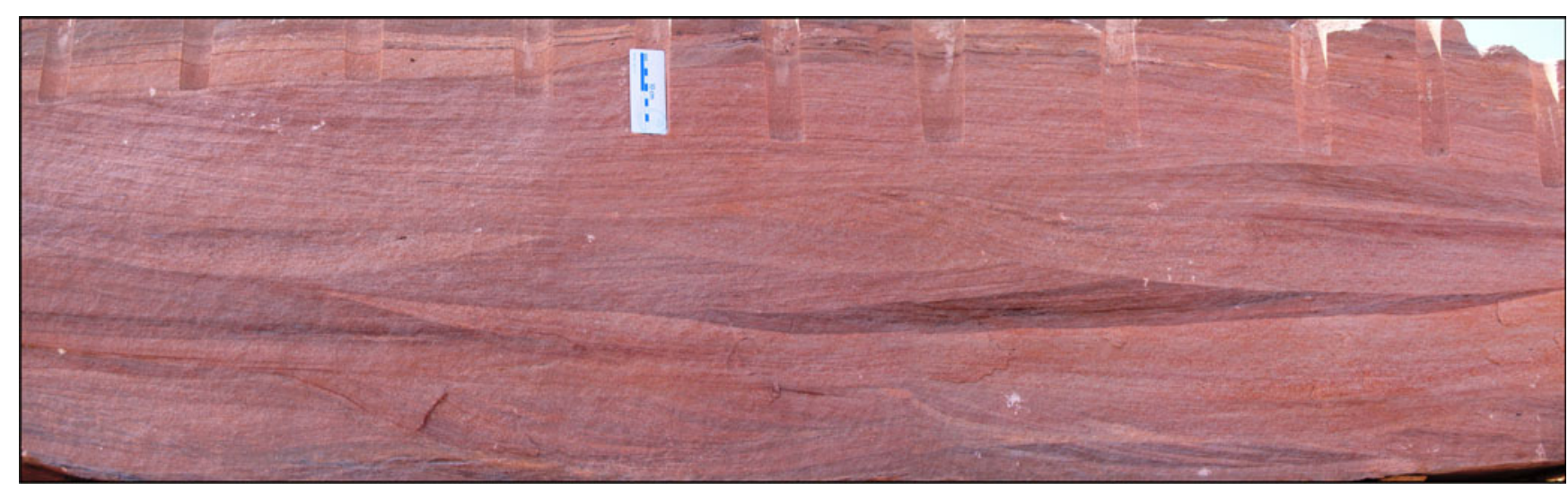

Figure 2. Alternation between chevron cross-stratification and plane lamination within the sandstones those expose the nodular structures. 


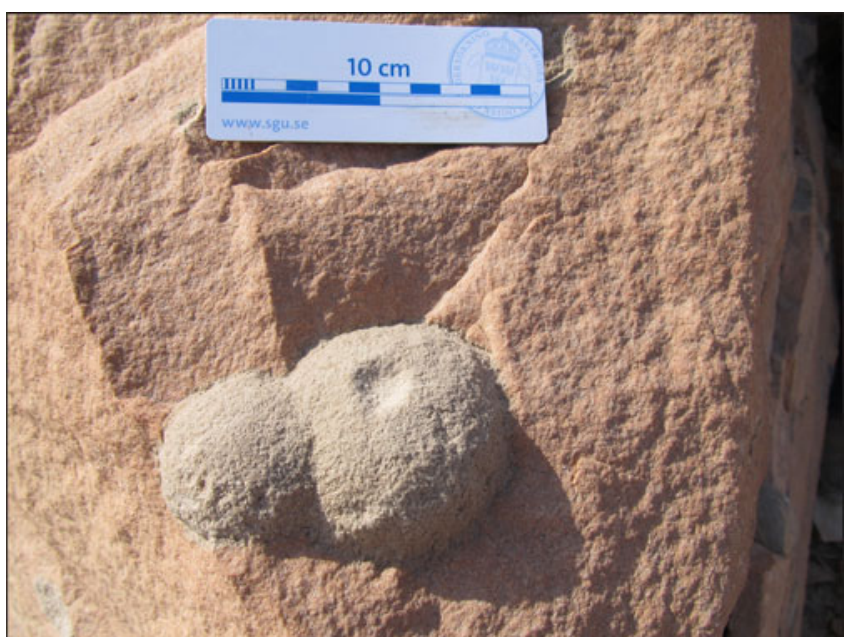

Figure 3. Bi-lobate Type-I nodule in bedding perpendicular section; note its intrabed occurrence.

Petrological studies of nodular sandstones reveal (i) common presence of dark reddish seams wrapping the margins of detrital grains (figure 5a), (ii) corrosion and rounding of detrital grains and frequent Fe-staining along the grain boundaries (figure 5b), (iii) silica represents the dominant cement component in the form of quartz overgrowth, iron oxides represent the subordinate cement variety in the form of dispersed dark brown clots and patches. It is interesting to note that despite availability of quartz as principal seed grain and silica as dominant cement variety, occurrence of quartz overgrowths are uneven and noticed locally, only in patches. Under SEM study, the silica cement is observed as amorphous, filling the pore voids between the detrital grains (figure $5 \mathrm{c}$ ). Compositionally, the silica cements record silica $(\mathrm{Si})$, carbon $(\mathrm{C})$ and iron $(\mathrm{Fe})$ in high concentration under EDAX analysis (figure 5d).

\subsubsection{Interpretation}

Domal structures with different dimensions are described by researchers as bedding plane features from Proterozoic shallow marine sandstones, e.g., the Mesoproterozoic Chorhat Sandstone, India (Sarkar et al. 2006, 2008) and the Ediacaran Kimberley region, northwestern Australia (Lan and Chen 2012) and interpreted as gas expulsion features triggered by decay of organic mat. But, description of intrabed domal features observed in bedding perpendicular sections is not available in literature. The biconvex morphology, homogeneous quartz composition and occurrence in beddingperpendicular section distinguish the presently described domal structures from the dewatering or load-triggered compaction structures (Mazzoli and Carnemolla 1993; Lan and Chen 2012). Also,

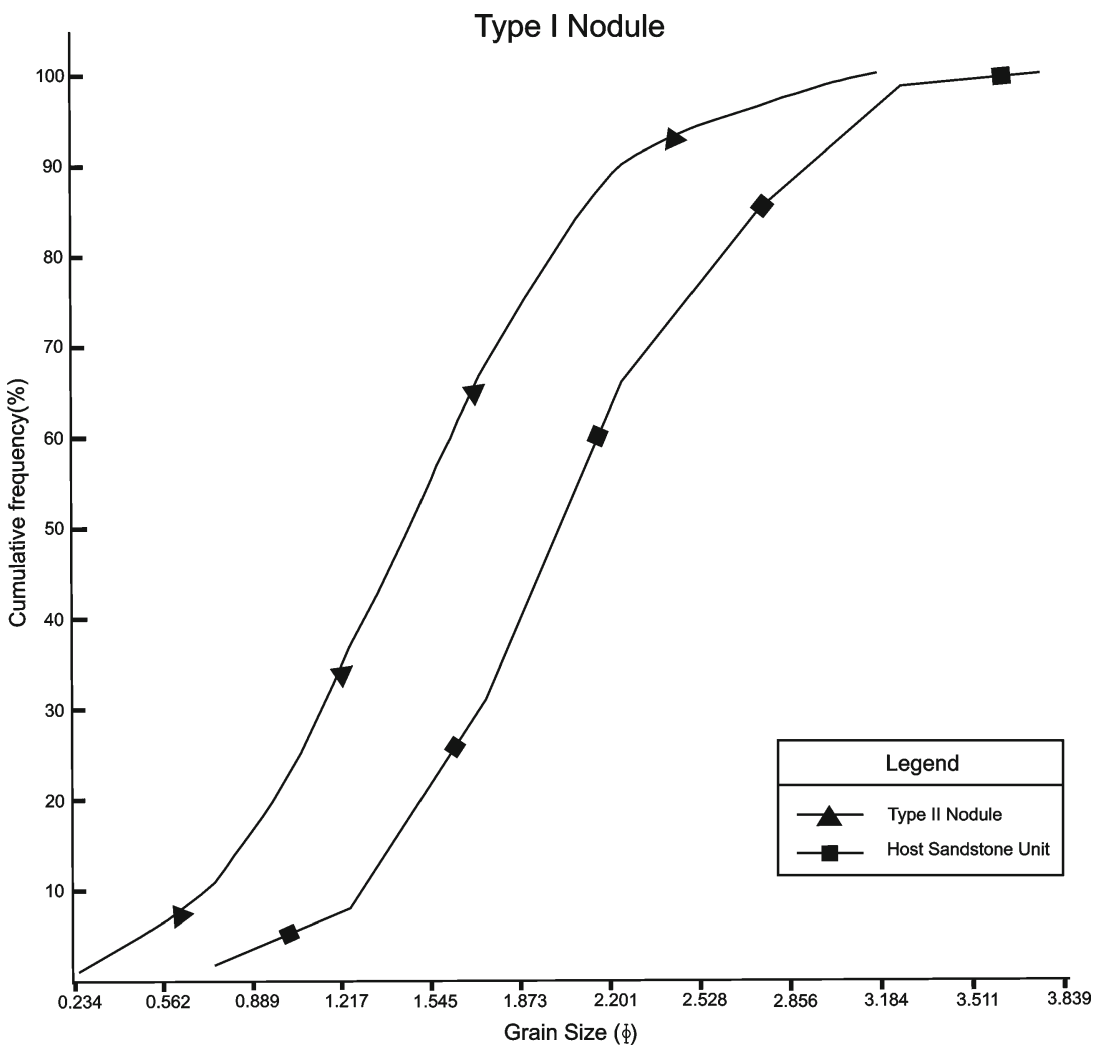

Figure 4. Cumulative frequency grain size distribution curves of samples $(n=07)$ collected from Type-I nodules and their immediate host sandstones. Note similar characters of two curves. 
Table 1. Comparative data on average grain size, sorting, skewness and percentage of cement present within Type-I nodule, its host sandstone and different parts of Type-II nodule and its overlying strata.

\begin{tabular}{|c|c|c|c|c|c|}
\hline $\begin{array}{l}\text { Nodule } \\
\text { type }\end{array}$ & Description of sample & $\begin{array}{l}\text { Avg. grain size } \\
\qquad\left(\mathrm{M}_{\mathrm{z}}\right)(\varnothing) \\
(\mathrm{n}=07)\end{array}$ & $\begin{array}{c}\text { Avg. std dev. } \\
\sigma_{\mathrm{i}}(\varnothing) \\
(\mathrm{n}=07)\end{array}$ & $\begin{array}{c}\text { Avg. } \\
\text { skewness } \\
\left(\mathrm{Sk}_{\mathrm{i}}\right)\end{array}$ & $\begin{array}{c}\text { Avg. } \\
\text { intergranular } \\
\text { cement }(\%)\end{array}$ \\
\hline \multirow{2}{*}{$\begin{array}{l}\text { Type I } \\
\qquad(\mathrm{n}=07)\end{array}$} & Samples from nodule $(\mathrm{n}=04)$ & 1.47 & 0.625 & 0.030 & $15 \%$ \\
\hline & Samples from host sandstone $(\mathrm{n}=03)$ & 2.06 & 0.634 & 0.030 & $6 \%$ \\
\hline \multirow{3}{*}{$\begin{array}{l}\text { Type II } \\
\qquad(\mathrm{n}=05)\end{array}$} & Samples from lower (body) part of nodule $(\mathrm{n}=02)$ & 1.96 & 0.536 & 0.583 & $5 \%$ \\
\hline & Samples from upper (neck) part of nodule $(\mathrm{n}=02)$ & 2.18 & 0.545 & 0.658 & $7 \%$ \\
\hline & Sample from the overlying strata $(n=01)$ & 1.8 & 0.513 & 0.507 & $5 \%$ \\
\hline
\end{tabular}
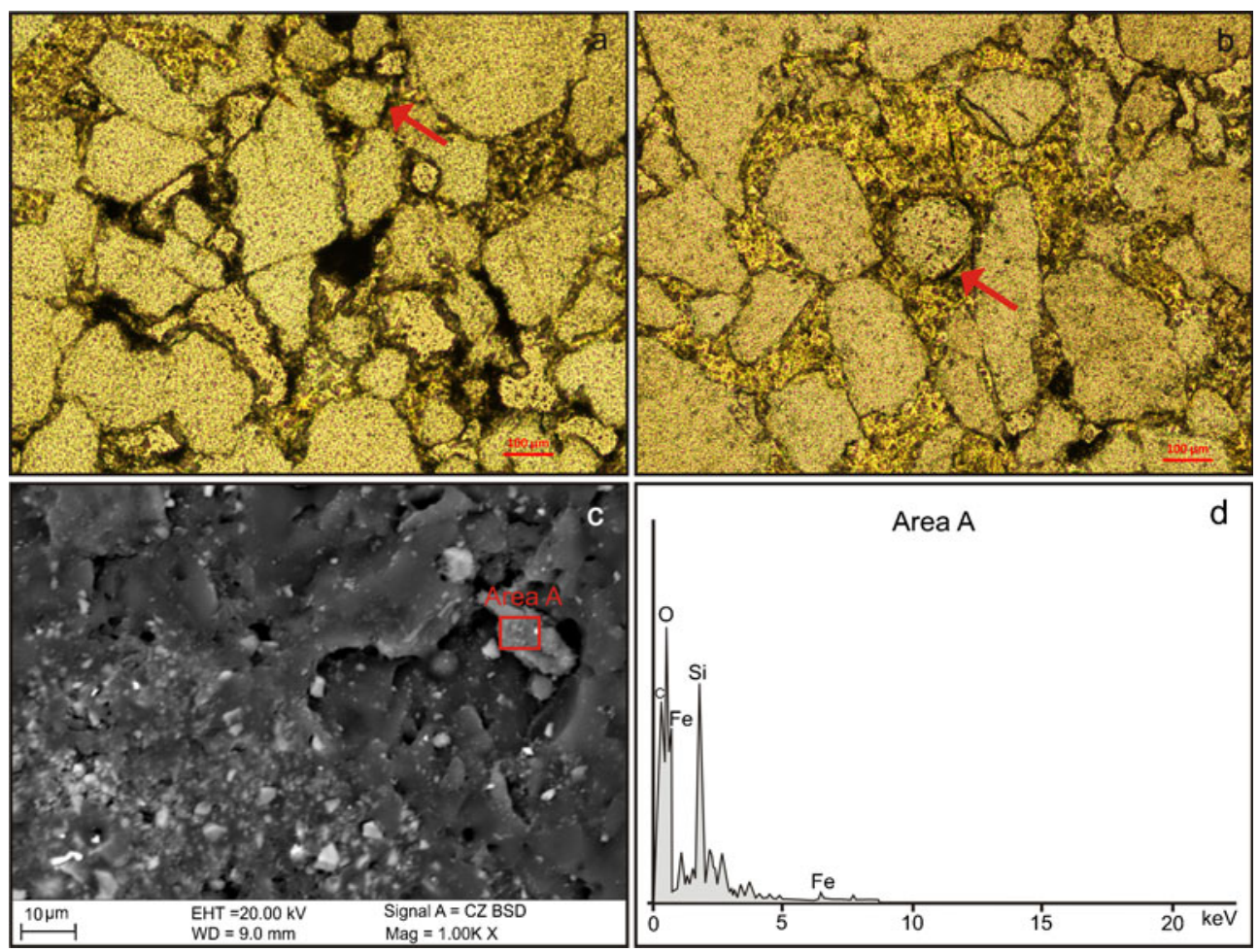

Figure 5. Photomicrographs (under plane polarized light) of Type-I nodule. (a) Coating of dark, ferruginous laminae around the framework grains (arrowed), (b) high percentage of cement, framework grains with rounded, sorbed boundary (arrowed), (c) SEM image showing amorphous character of cement, and (d) EDAX analysis of cement showing high peaks of Fe, C and Si.

relatively steep sides of these domes (steeper than the angle of repose) are incompatible with the idea of any current- or wave-induced bedform deformation origin (Sarkar et al. 2008). No significant difference in the granulometric characters between the nodule sandstones and their surrounding sandstones also rules out any depositional heterogeneity behind formation of these nodules. With this background, we are inclined towards inferring organic (microbial/bacterial) mat mediated origin for the observed domal structures.

Microbial colonization on sandy sediment surfaces are well documented, particularly when sedimentation rates are sufficiently small. Sarkar et al. (2008) inferred an overall low rate of sedimentation for the Sonia Sandstone with prolific mat growth at times of sedimentation hiatuses. In sandstones, with comparatively high permeability, organic matter is readily metabolised by microbes during early burial. Redox reactions resulting in organic decay may generate gases like $\mathrm{CO}_{2}, \mathrm{CH}_{4}$ and $\mathrm{H}_{2} \mathrm{~S}$ at shallow burial depth (Logan et al. 1974; Skyring et al. 1989). For a reasonably thick and laterally persistent microbial mat layer, the gas thus generated below the mat unit will aid in the development of oxic-anoxic boundary. With the increase in the physical stress (i.e., vapour pressure, $V_{p}$ ) produced by the accumulation of gases overceeding the hydrostatic pressure $\left(P_{w}\right)$ of overlying sedimentwater column, the gas migrates from deeper, 
buried organic deposits through delicate gas escape channels (Gerdes et al. 1993; Sarkar et al. 2004; Banerjee et al. 2010; Lan and Chen 2012). For gas domes described from sediment upper surface, the gas channels are visualised as near vertical bringing the gas charged sediments towards the surface where cohesive microbial tissues inhibit escape of the gas into air or water resulting upward doming of the surface. But, such situation cannot be conceived if the microbial mat layer is laterally impersistent or is not of sufficient thickness. Neither a well-defined oxic-anoxic boundary will form, nor will the low-volume buried organic matter generate enough gas pressure $\left(V_{p}\right)$ which will be sufficient to exceed the hydrostatic pressure $\left(P_{w}\right)$ and vent out vertically through the escape channels. But, the generated gas pressure may be sufficient to cause rarefication of local grain packing, and also because of higher relative permeability of gas, the water in the pore spaces may be pushed away (figure 6). An increased pore water pressure $\left(P_{p}=\right.$ $\left.P_{w}+\delta P_{w}\right)$ will be generated within the adjacent sediments that may result in their massiveness. We intend to relate the origin of intrabed domal structures with such organic (microbial) mat generated gas pressure $\left(V_{p}\right)$ which is high to cause grain rarefication, but not high enough to vent out by overceeding the hydrostatic pressure. The higher porosity (represented by high cement content) of nodule sandstones in comparison to their adjacent sandstones and the massiveness of adjacent sandstones corroborate the contention.

The siliciclastic mineral grains, when deposited in a mat-influenced environment, tend to be coated by organic substances (Johnston et al. 2005; Schieber et al. 2007). The occurrences of dark reddish ferruginous seams around the detrital grains and iron oxide clots within the nodule sandstones bear indication of organic coating (Garlick 1988; Schieber 1999; Banerjee and Jeevankumar 2005; Banerjee et al. 2006a; Schieber et al. 2007; Samanta et al. 2011). Similar features interpreted as signatures of microbial mat growth from the Mesoproterozoic Revett Formation, Belt Supergroup, Montana (Garlick 1988; Schieber et al. 2007) and Chorhat Sandstone Formation, Vindhyan Supergroup, India (Sarkar et al. 2006).

Our model envisages an early diagenetic localized amorphous silica cementation behind the formation of these nodules. The $9 \%$ high cement content within the nodule sandstones bear signature in favour of this claim. From the study of amorphous silica-quartz equilibrium at temperature range between $0^{\circ} \mathrm{C}$ and $200^{\circ} \mathrm{C}$, Siever
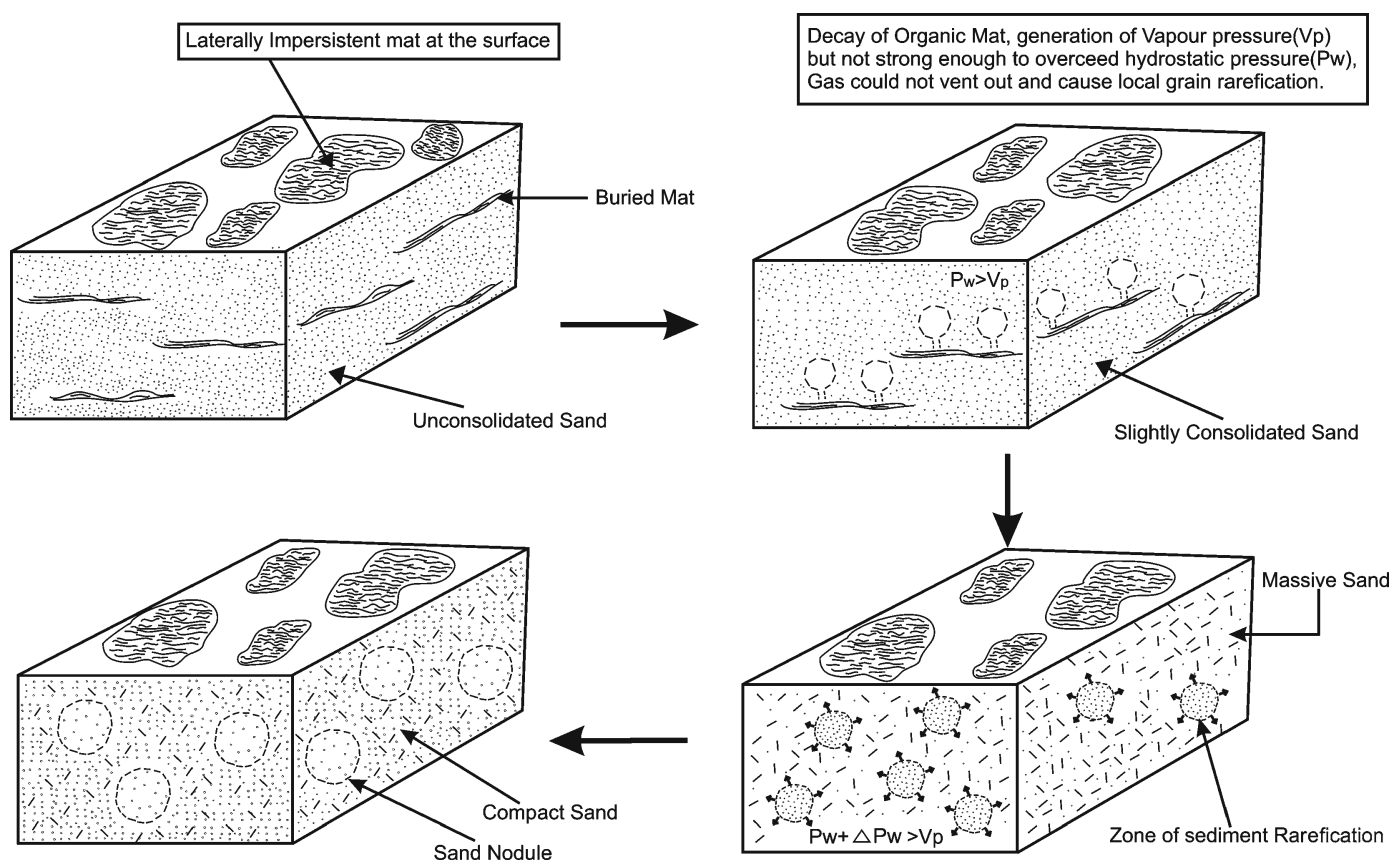

Due to further compaction, SRZ solidifies and form nodular structures.

Higher relative permeability of gas pushes away pore water out of sediment rarefication zone(SRZ). High gas pressure reduces Ph in SRZ and promotes silica cementation.

Figure 6. Schematic step-wise representation of model proposed for Type-I nodule formation. Note patchy growth of organic mat, their shallow burial, decay and generation of gas pressure $\left(V_{p}\right)$. Increased confined gas pressure forces grain rarefication on one hand and simultaneously encourages early silica cementation by reduction in pore water $\mathrm{Ph}$. 
(1962) observed that at low temperature because of metastable equilibrium of amorphous silica and difficulty in quartz crystallisation, silica gets precipitate at amorphous state. If we consider sediment containing both quartz and amorphous silica, we may expect that the amorphous silica will gradually dissolve and quartz will precipitate. However, this will not be the case if there is presence of organic matter as adsorbed material on the silica surface, which will not allow silica to equilibrate with the surrounding water. Occurrence of ferruginous coats around the grains and high $\mathrm{C}$ and Fe peaks in EDAX analysis confirm the presence of relatively higher amount of organic matter at the stage of shallow burial diagenesis, possibly in the form of microbial mat coating. The organic matters helped in silica precipitation and early cementation by two ways: (i) decay at shallow burial, generation of gases like $\mathrm{CO}_{2}, \mathrm{CH}_{4}$, etc. and thereby decrease in pore water $\mathrm{Ph}$, possibly below 7 , which decreased solubility of silica drastically, and (ii) by providing local seeds or templates to help silica nucleate (Knoll 1985; Simonson 1987). The amorphous silica cementation, in patches as fringe-cement, at the early stage of burial caused partial lithification of the sandstone and triggered inhomogeneous diagenetic behaviour on further burial. Whereas the earlier lithified portions of the sandstone resisted compaction under further burial, the rest of the sandstone underwent compaction. Initial primary difference in the sediment has been accentuated in the later diagenesis by relatively less compaction. The lower percentage of cement (table 1) and development of planar grain contacts, often sutured, within host sandstones corroborate the contention of higher compaction.

\subsection{Type II}

This variety of nodules resembles the geometry of pitcher (figure $7 \mathrm{a}, \mathrm{b}$ ). In contrast to the Type-I nodules, this type of nodules involve several strata (both thick- and thin-bedded) and are meters-scale in dimension. Careful search could not identify any such structure in the overlying and underlying stratigraphic levels although detailed field and petrological observations confirm their nearly uniform petrographic and granulometric characters. No difference in colour, mineralogy or texture
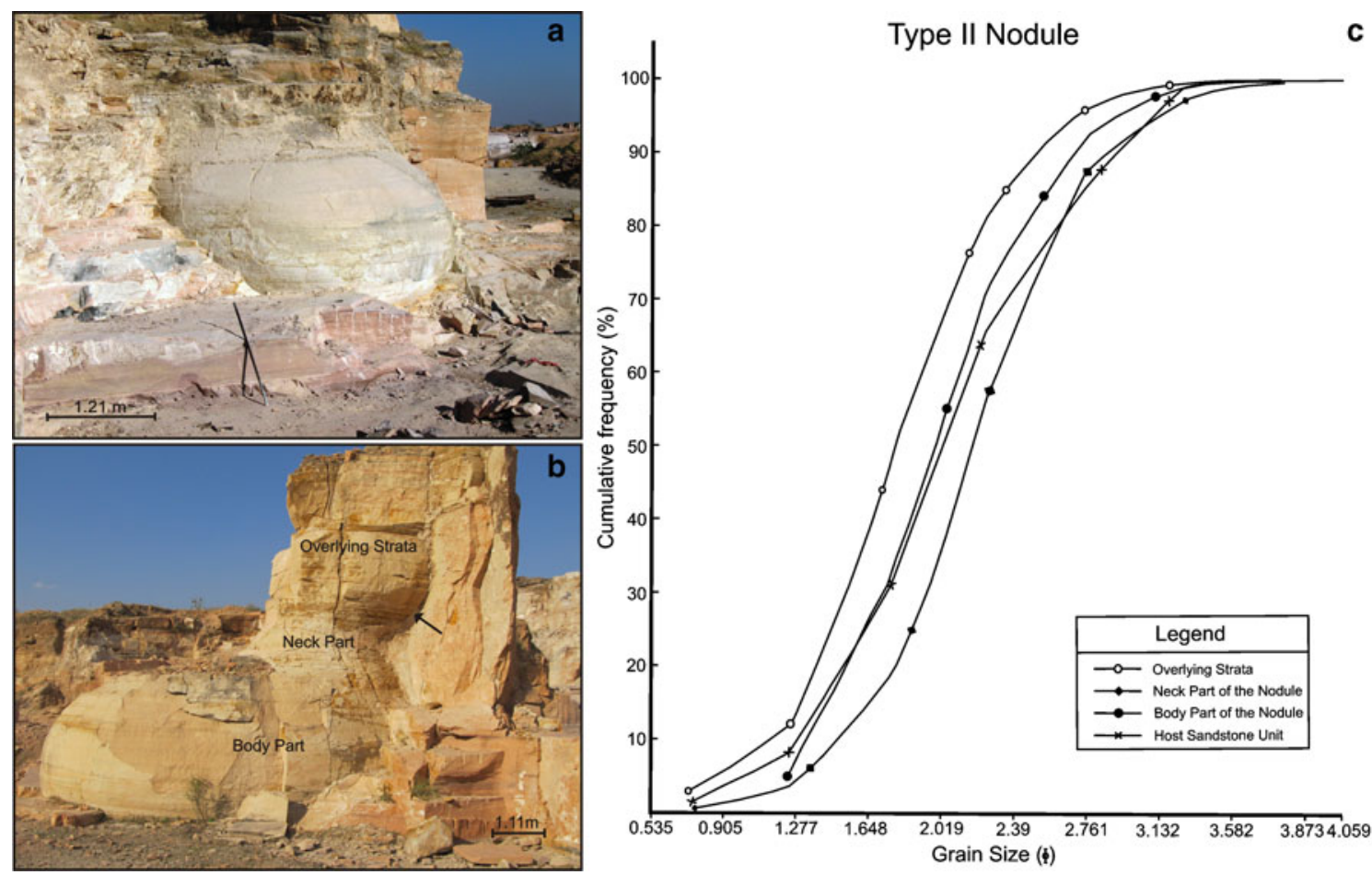

Figure 7. (a) Type-II nodule (cf. giant nodule of Kumar et al. 2011) sandwiched between undisturbed, subhorizontal strata. (b) Pitcher shape of the nodule with well defined body and neck parts. Note near vertical fracture bounding the nodule (arrowed). Also note refraction of fracture across the thick- and thin-bedded sandstone boundary. (c) Cumulative frequency grain size distribution curves of samples $(n=05)$ collected from the Type-II nodule (its body and neck part), overlying strata and adjacent host sandstone. Note similarity in all the characters of grain size distribution of samples except that the sandstone from the neck part of the nodule is of relatively smaller grain size compared to sandstones in the body part and overlying strata. 
is observed between the nodules and their host sandstones and no nodules display any concentric structure in their cross-sections. An individual pitcher is comprised of both thin- and thickbedded strata representing its neck and body parts, respectively. Maximum diameter, neck diameter and height of the pitchers vary between 3 and $6 \mathrm{~m}$, 1.5 and $4.1 \mathrm{~m}$, and 2 and $6.2 \mathrm{~m}$, respectively. Close observation of the outcrops revealed continuation of laminations across the boundary of the pitchers well within the associated rocks. The inclination amounts measured on the margin of these nodules vary between $68^{\circ}$ and $84^{\circ}$.

Fracture systems with dip amount varying between $21^{\circ}$ and $80^{\circ}$ dissect the stratal package in the stratigraphic level that exposes the nodular structures. In vertical section, a pitcher is confined between two adjacent curvilinear refracting fractures those transgress both the thick- and thinbedded lithologies. Though intersection between the two sets of fractures has not been encountered in outcrop, stereonet plotting of fracture planes and their $\beta$ pole plots (figure $8 \mathrm{a}, \mathrm{b}$ ) suggest projected low angle intersection of two sets of fracture on a plane at a high angle to the bedding plane. Results of grain size analyses for sandstones collected from (a) lower (body) part, (b) upper (neck) part of the nodule and (c) overlying bed are summarised in table 1. Sandstones from both the nodules and their overlying beds are fine to medium sand size $\left(\mathrm{M}_{\mathrm{z}}\right.$ range between 1.8 and $\left.2.18 \Phi\right)$, moderately well sorted $\left(\sigma_{\mathrm{i}}(\Phi)=0.51\right.$ to $\left.0.53 \Phi\right)$ and with finely skewed $\left(\mathrm{Sk}_{\mathrm{i}}=0.50\right.$ to 0.65$)$ character. However, close observation (figure 7c, table 1) revealed that the neck part of the nodule is represented by relatively smaller grained $\left(\mathrm{M}_{\mathrm{z}}=2.18 \Phi\right.$; thin bedded wave rippled) sandstones compared to both the body part of the nodule $\left(\mathrm{M}_{\mathrm{z}}=2.01 \Phi\right.$; thick bedded chevron cross-stratified) and the overlying strata $\left(\mathrm{M}_{\mathrm{z}}=1.8 \Phi\right)$. No difference in the intragranular cement content is noticed between nodule sandstones and the sandstones collected from immediate overlying strata.

\subsubsection{Interpretation}

Describing as 'Giant nodule', Kumar et al. (2011) proposed a diagenetic origin for these nodules and suggested possibility of variation in silica cement content between the nodules and their associated sandstones. These researchers neither cited any petrographic or modal analysis data nor provided documentation of variation in the volume of silica cement in favour of their conclusion. Except for the subtle grain size fining in the thin-bedded sandstones from the neck part of the nodules, the present study does not observe any marked difference in the granulometric parameters, viz., sorting and skewness values (table 1) or in the intragranular cement content between the nodule sandstones and their host. Lack of any significant difference in the cement content between the nodules and their host sandstones rules out the possibility of secondary silica cementation as the principal cause behind formation of this variety of nodules as suggested by Kumar et al. (2011). Presence of fresh, compact sandstones both above and below the nodular structures also rules out the possibility of formation of these nodules solely by weathering either.

Instead, we propose a model in which bedtransgressive near vertical fractures are identified as the possible forcing behind the nodule formation (figure 9a, b). Presence of near vertical fracture set is a prominent feature in the stratigraphic
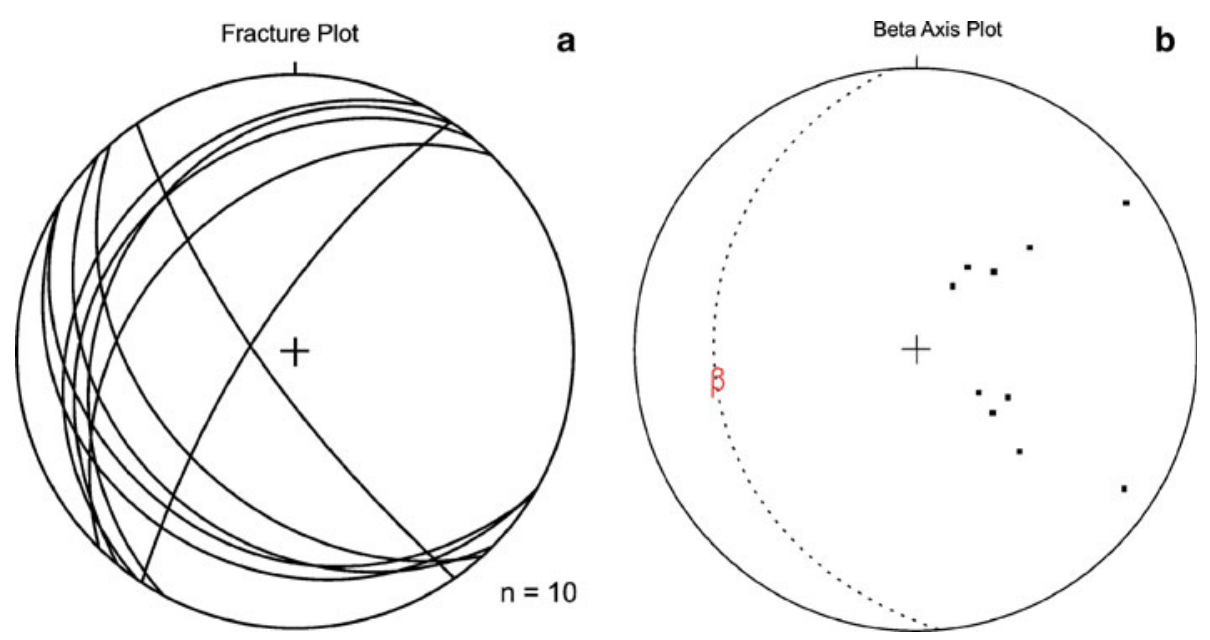

Figure 8. Stereo plotting of fracture attitudes associated with Type-II nodule (a) plotting of fracture planes and (b) poles of fracture planes ( $\beta$ pole). 
a

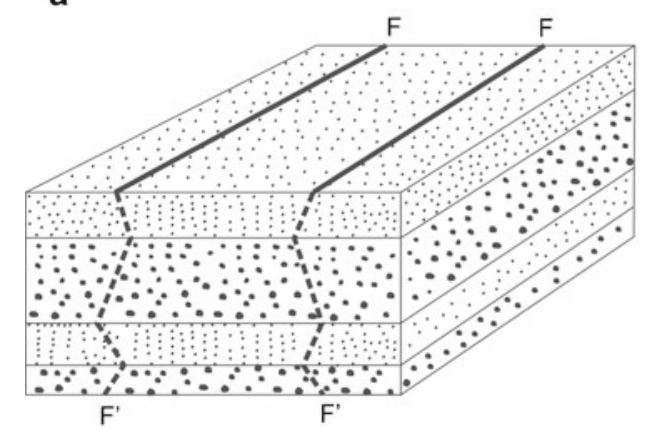

$\because \quad$ Thicker medium grained sandstone

Thinly bedded fine grained sandstone

Fractures in plan and section;"Note refraction of fracture across the lithological boundaries".

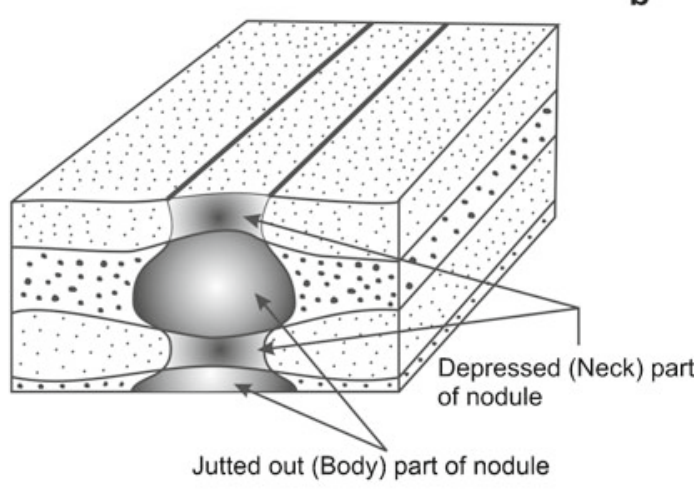

b

Figure 9. Cartoon illustrating origin of Type-II nodule; (a) Refraction of fracture across the lithological boundaries, convergence of adjacent fractures in thinly-bedded finer grained strata and their divergence in thick-bedded, coarser grained units and (b) with superimposed weathering effect generation of pitcher shape for the nodules.

interval that exposes this variety of nodules. Our model proposes that the refraction of these fractures across the boundary of thick- and thinbedded strata is the crucial reason behind the pitcher shape of these nodules. In passing from the thick, compact to the thin-bedded finer grained strata, a fracture makes a lower angle with the bedding (figure 9a) compared to when it passes from the thin- to the thick-bedded strata. This will cause convergence of two adjacent fractures in the thinbedded strata and their divergence in thick bedded strata. Convergence of two adjacent fractures possibly resulted in the necking effect at the upper and lower boundaries of thick-bedded strata as their divergence within the thick-bedded strata shaped the main body part of the pitcher (figure $9 \mathrm{~b}$ ). The necking effect was further reinforced by relatively finer grain size within the thin-bedded strata which allowed its higher weathering and thereby makes this part appear as depressed compared to the jutted out body part of the pitcher.

\section{Discussion}

The Sonia Sandstone exposed in the Sursagar Mine area near the Jodhpur town, Rajasthan exhibits spectacular nodular structures which vary not only in scale and geometry but also in their mode of occurrence and origin. Among the two types of nodules, the Type-I nodules are of small size and intrabed in occurrence, whereas Type II are of giant-sized and observed transgressing several bed boundaries. Though the nodules are restricted within a particular stratigraphic level, they demonstrate wide variation in genetic history. The study proposes a post-sedimentation organic mat mediated early cementation origin for the Type-I nodules and a post-lithification fracture-controlled origin for the Type-II nodules, respectively.

The Type-I nodules are unique in the sense that they are intrabed in occurrence and caused by early lithification and hardening of sandstone with microbial mat decay provoked amorphous silica cementation at shallow burial stage. This conjecture goes against the commonly held belief that the formation of nodules (concretions) at the diagenetic stage is caused essentially by the secondary silica cementation from aqueous solution. As such, early cementation and hard ground formation is a well known hypothesis in sea floor diagenesis of carbonate sediments (Chanda et al. 1977; James and Choquette 1983; Tucker and Wright 1990; Banerjee et al. 2005; Banerjee and Jeevankumar 2007). On the contrary, the role of early cementation is always undermined in the diagenetic history of siliciclastic sediments. Neither, the effect of presence of organic matter in the silica cementation process of sandstones are studied and documented in detail for nodule formation, despite the experimental understanding (Siever 1962; Knoll 1985; Simonson 1987) that the presence of organic matter has a considerable role in the solubility and precipitation of silica at low temperature range. Through detailed petrography and SEM-EDAX analysis, the present study proposes an alternative mechanism by which the thin and laterally impersistent microbial matter on decay generates vapour pressure not sufficient enough to overcome the hydrostatic pressure. We suggest that in such case the increased vapour pressure will cause local rarefication of grain packing, push away the pore water and will promote 
amorphous silica precipitation by creating local anoxicity. The model also provides an explanation for the massiveness of host sandstone with increased pore pressure hypothesis.

Appreciation of fracture system and their control on the shape of Type-II nodules allowed us to propose an alternative hypothesis for nodule formation at the post-lithification stage, going beyond the secondary mineralisation hypothesis put forward as panacea for diagenetic nodule formation. Lithology guided refraction of fractures assisted by higher weathering in finer grained strata is identified as an alternative mechanism for giant pitcher-shaped nodule formation in alternated thick- and thinbedded medium grained sandstones. The study warrants detailed investigation of diagenetic nodules involving petrography and structural analysis before coming to conclusion in favour of a secondary mineralisation origin.

\section{Conclusion}

- The medium grained Proterozoic Sonia Sandstone of Marwar Supergroup exposes spectacular range of nodules near Sursagar area, Jodhpur, which are classified under two types; Type I (intrabed) and Type II (interbed).

- Type I nodules are originated by early cementation in shallow burial diagenesis. Decay of organic matter, generation of vapour pressure and anoxicity, local grain rarefication and amorphous fringe-cementation of silica caused the early heterogeneity in sandstone. Later diagenesis and compaction accentuated the effect and helped in nodule formation.

- Differing from the earlier proposed secondary mineralisation hypothesis, the present study proposes a post-lithification fracture controlled origin for the Type II nodules. Lithology guided refraction of fractures assisted by higher weathering of finer grained strata is identified as an alternative mechanism for these giant pitcher-shaped nodules.

- The study warrants study of other sandstone hosted nodular structures to see the possibility of different modes of origin for these structures beyond the simplistic secondary mineralisation origin.

\section{Acknowledgements}

The authors thankfully acknowledge research funding from University of Delhi. Department of Geology, University of Delhi provided necessary infrastructure and instrumental facilities.

\section{References}

Banerjee S and Jeevankumar S 2005 Microbially originated wrinkle structures on sandstone and their stratigraphic context: Palaeoproterozoic Koldaha Shale, central India; Sedim. Geol. 176 211-224.

Banerjee S and Jeevankumar S 2007 Facies and depositional sequence of the Mesoproterozoic Rohtas Limestone, eastern Son valley, India; J. Asian Earth Sci. 30 82-92.

Banerjee S, Sarkar S and Bhattacharyya S K 2005 Facies, dissolution seams and stable isotope characteristics of the Rohtas Limestone (Vindhyan Supergroup) in the Son valley area, central India; J. Earth Syst. Sci. 114 87-96.

Banerjee S, Bhattacharya S K and Sarkar S 2006a Carbon and oxygen isotope compositions of the carbonate facies in the Vindhyan Supergroup, central India; J. Earth Syst. Sci. 115 113-134.

Banerjee S, Jeevankumar S, Sanyal P and Bhattacharyya S K 2006b Stable isotope ratios and nodular limestone of the Proterozoic Rohtas Limestone, Vindhyan basin, India; Carbonates and Evaporites 21 133-143.

Banerjee S, Sarkar S, Eriksson P and Samanta P 2010 Microbially related structures in siliciclastic sediment resembling Ediacaran fossils: Examples from India, ancient and modern; In: Microbial Mats: Modern and Ancient Microorganisms in Stratified Systems (eds) Seckbach J and Oren A (Berlin: Springer-Verlag) 14 111-129.

Bose P K, Eriksson P G, Sarkar S, Wright D T, Samanta P, Mukhopadhyay S, Mandal S, Banerjee S and Altermann W 2012 Sedimentation patterns during the Precambrian: A unique record?; Marine Petrol. Geol. 33 34-68.

Chanda S K, Bhattacharya A and Sarkar S 1977 Early diagenetic chert nodules in Bhander Limestone, Satna district, Maihar, India; J. Geol. 84 213-224.

Chauhan D S 1999 Tectonic and sedimentary evolution of the Marwar basin: A Neoproterozoic-Early Cambrian intracratonic sag basin; In: Proceedings of the Seminar on Geology of Rajasthan - Status and Perspective (ed.) Kataria P (A.B. Roy Felicitation Volume) Geology Department, MLSU, Udaipur, pp. 111-125.

Das Gupta S K 1996 Marwar Supergroup evaporates, Rajasthan; In: Recent advances in Vindhyan Geology (ed.) Ajit Bhattacharyya; Geol. Soc. India Memoir $\mathbf{3 6}$ 49-58.

Das Gupta S K and Bulgauda S S 1994 An overview of the geology and hydrocarbon occurrence in western part of Bikaner-Nagaur basin; Indian J. Petrol. Geol. 3(1) $1-17$.

Folk R L and Lynch F L 1997 The possible role of nanobacterial (dwarf bacteria) in clay-mineral diagenesis and the importance of careful sample preparation in highmagnification SEM study; J. Sedim. Res. 67 583-589.

Garlick W G 1988 Algal mats, load structures, and synsedimentary sulfides in Revett quartzites of Montana and Idaho; Econ. Geol. 83 1259-1278.

Gerdes G, Claes M, Dunajtschik-Piewak K, Riege H, Krumbein W E and Reineck H E 1993 Contribution of microbial mats to sedimentary surface structures; Facies 29 61-74.

James N P and Choquette P W 1983 Diagenesis 6. Limestones - The seafloor diagenetic environment; Geoscience Canada 10 162-179.

Johnston D T, Wing B A, Farquhar J, Kaufman A J, Strauss H, Lyons T W, Kah L C and Canfield D E 2005 Active microbial sulfur disproportionation in the Mesoproterozoic; Science 310 1477-1479.

Knoll A H 1985 Exceptional preservation of photosynthetic organisms in silicified carbonates and silicified peats; Phil. Trans. Roy. Soc. London, Ser. B 311 111-122. 
Kumar S, Pandey S K and Ahmad S 2011 Occurrence of giant nodules in the jodhpur sandstone, Sursagar area, Jodhpur, Rajasthan; Curr. Sci. 100(9) 1294-1296.

Lan Z W and Chen Z Q 2012 Exceptionally preserved microbially induced sedimentary structures from the Ediacaran post-glacial successions in the Kimberley region, northwestern Australia; Precamb. Res. 200-203 $1-25$.

Logan B W, Hoffman P and Gebelein C D 1974 Algal mats, cryptalgal fabrics, and structures, Hamelin Pool, Western Australia; In: Evolution and Diagenesis of Quaternary Carbonate Sequence Shark Bay West Australia (eds) Logan B W, Hoffman P, Gebelein C D; AAPG Memoir 22 140-194.

Malone S J, Meert J G, Banerjee D M, Pandit M K, Tamrat E, Kamenov G D, Pradhan V R and Sohl L E 2008 Paleomagnetism and Detrital Zircon Geochronology of the Upper Vindhyan Sequence, Son Valley and Rajasthan, India: A ca. 1000 Ma age for the Purana Basins?; Precamb. Res. 164 137-159.

Mazumdar A and Bhattacharya S K 2004 Stable isotopic study from late Neoproterozoic-early Cambrian (?) sediments from Nagaur-Ganganagar Basin, western India: Possible signatures of global and regional C-isotopic events; Geochem. J. 38 163-175.

Mazzoli S and Carnemolla S 1993 Effects of the superposition of compaction and tectonic strain during folding of a multilayer sequence - model and observations; J. Struct. Geol. 15 277-291.

McBride E F, Picard M D and Folk R L 1994 Oriented concretions Ionian coast, Italy: Evidence of groundwater flow direction; J. Sedim. Res. A64 535-540.

Molenaar N and Martinius A W 1990 Origin of nodules in mixed siliciclastic-carbonate sandstones, the Lower Eocene Roda Sandstone Member, southern Pyrenees, Spain; Sedim. Geol. 66 277-293.

Moller N K and Kvingan K 1988 The genesis of nodular limestones in the Ordovician and Silurian of the Oslo Region; Sedimentology 35 405-420.

Mozley P S and Davis J M 1996 Relationship between oriented calcite concretions and permeability correlation structure in an alluvial aquifer, Sierra Ladrones Formation, New Mexico; J. Sedim. Res 66 11-16.

Pareek H S 1984 Pre-Quaternary geology and mineral resources of northwestern Rajasthan; Geol. Surv. India Memoir 115 1-95.

Pettijohn F J 1984 Sedimentary rocks (3rd edn), Harper and Row Publ., 628p.

Pomar L, Westphal H and Obrador A 2004 Oriented calcite concretions in upper miocene carbonate rocks of menorca, Spain: Evidence for fluid flow through a heterogeneous porous system; Geologica Acta 2 271-284.

Rahmani R A 1970 Carbonate concretions in the Upper Cretaceous Cedar District Formation, British Columbia; Bull. Can. Pet. Geol. 18 282-288.

Raiswell R 1971 The growth of Cambrian and Liassic concretions; Sedimentology 17 147-171.

Rathore S S, Venkatesan T R and Srivastava R K 1996 $\mathrm{Rb}-\mathrm{Sr}$ and $\mathrm{Ar}-\mathrm{Ar}$ systematics of Malani volcanic rocks of southwest Rajasthan: Evidence for a younger post- crystallization thermal event; Proc. Indian Acad. Sci. (Earth Planet. Sci.) 105 131-141.

Rathore S S, Venkatesan T R and Srivastava R K 1998 $\mathrm{Rb}-\mathrm{Sr}$ isotope dating of Neoproterozoic (Malani Group) magmatism from southwest Rajasthan, India: Evidence of younger Pan-African thermal event by $40 \mathrm{Ar}-39 \mathrm{Ar}-$ studies; Gondwana Res. 2(2) 271-281.

Samanta P, Mukhopadhyay S, Mondal A and Sarkar S 2011 Microbial mat structures in profile: The Neoproterozoic Sonia sandstone, Rajasthan, India; J. Asian Earth Sci. $40542-549$.

Sarkar S, Banerjee S and Eriksson P G 2004 Microbial mat features in sandstones illustrated; In: The Precambrian Earth: Tempos and Events (eds) Eriksson P G, Altermann W, Nelson D R, Mueller W U and Catuneanu O, Dev. Precamb. Geol. (Elsevier: Amsterdam) 12 673-675.

Sarkar S, Banerjee S, Eriksson P G and Catuneanu O 2005 Microbial mat control on siliciclastic Precambrian sequence stratigraphic architecture: Examples from India; Sedim. Geol. 176 195-209.

Sarkar S, Banerjee S, Samanta P and Jeevankumar S 2006 Microbial mat induced sedimentary structures in siliciclastic sediments: Examples from the 1.6 Ga Churhat Sandstone, Vindhyan Supergroup, M.P., India; J. Earth Syst. Sci. 115(1) 49-60.

Sarkar S, Bose P K, Samanta P, Sengupta P and Eriksson G 2008 Microbial mat mediated structures in the Ediacaran Sonia Sandstone, Rajasthan, India, and their implications for Proterozoic sedimentation; Precamb. Res. 162 248263.

Sarkar S, Samanta P, Mukhopadhyay S and Bose P K 2012 Stratigraphic architecture of the Sonia Fluvial interval, India in its Precambrian context; Precamb. Res. 214-215 210-226.

Schieber J 1999 Microbial mats in terrigenous clastics: The challenge of identification in the rock record; Palaios 14 3-12.

Schieber J, Bose P K, Eriksson P G, Banerjee S, Sarkar S, Altermann W and Catuneau O 2007 Atlas of microbial mat features preserved within the siliciclastic rock record; Atlases in Geosciences, Elsevier, 311p.

Siever R 1962 Silica solubility, $0^{\circ} \mathrm{C}-200^{\circ} \mathrm{C}$, and the diagenesis of siliceous sediments; J. Geol. 70(2) 127-150.

Simonson B M 1987 Early silica cementation and subsequent diagenesis in arenites from four early Proterozoic iron formations of North America; J. Sedim. Petrol. 57 494-511.

Skyring G W, Lynch R M and Smith G D 1989 Quantitative relationships between carbon, hydrogen and sulphur metabolism in cyanobacterial mats; In: Physiological Ecology of Benthic Microbial Communities (eds) Cohen $\mathrm{C}$ and Rosenberg E, Microbial Mats, American Society of Microbiology, pp. 170-179.

Theakstone W H 1981 Concretions in glacial sediments at seglvetnet, Norway; J. Sedim. Petrol. 51 191-196.

Tucker M E and Wright V P 1990 Carbonate sedimentology; Blackwell Science, 422p.

Valdiya K S 1999 Marwar's connection with the Himalayas; In: Geological Evolution of Northwestern India (ed.) Paliwal B S, Scientific Publishers India, pp. 1-18. 